\title{
Synthesis, Characterization and Biological Evaluation of New Schiff Base Ligand derived from 3-hydroxy-benzaldehyde and $p$-toluidine and its Divalent Metal Ions
}

\author{
NOREEN MAZHAR ${ }^{1}$, MEHWISH AFTAB ${ }^{1}$, TARIQ MAHMUD ${ }^{1 *}$, \\ MUHAMMADASIM RAZA BASRA ${ }^{1}$, MANSOOR AKHTAR ${ }^{2}$, LIVIU MITU ${ }^{3 *}$ \\ ${ }^{1}$ Institute of Chemistry, University of Punjab, Quaid-e-Azam Campus, Lahore-54590, Pakistan \\ ${ }^{2}$ Faculty of Chemistry, Northeast Normal University, Changchun 130024, Jilin, People's Republic of China ${ }^{3}$ Department of \\ ${ }^{3}$ University of Pitesti, Nature Sciences, 1 Targu din Vale, 110040, Pitesti, Romania
}

\begin{abstract}
A new Schiff base ligand $(L)$ and its transition divalent metal complexes were prepared by the condensation reaction; Reaction was carried out at $70-80{ }^{\circ} \mathrm{C}$ by refluxing equimolar ratio of toluidine and aldehyde by continuous stirring for 5-6 hours. Synthesized ligand and Ni(II), Fe(II), $\mathrm{Co}(I I), \mathrm{Mn}(I I)$ and $\mathrm{Zn}(\mathrm{II})$ bimetallic complexes were characterized by using FT-IR, UV-visible spectroscopy, AAS, Single crystal X-ray analysis, ${ }^{1} H$-NMR, molar conductance. Compounds were screened against two fungus Candida glabrata and Candida albicans by agar tube dilution protocol. In vivo anti-inflammatory activity via induced paw edema method and in vitro results by heat induced protein denaturation method were checked. Synthesized compounds were also showed antioxidant activity by using DPPH (diphenylpicrylhydrazyl) and Trolox was used as standard. These studies show that ligand and almost all metal complexes are reactive towards biological assays against reported standard drugs. Zn-L indicates more activeness for antioxidant activity and free ligand while Co- $L$ recognized as more effective anti-inflammatory drug.
\end{abstract}

Keywords: Schiff base, Metal complexes, Antioxidant, Anti-inflammatory, Carrageenan

\section{Introduction}

Schiff bases were discovered first time by the chemist Hugo Schiff in 1864 [1]. These are condensation products of carbonyl compounds and amines [2], also called as imine or azomethine due to $(-\mathrm{HC}=\mathrm{N}-)$ functional group [3], here nitrogen atom serves as bonding molecule for complexation.In azomethine derivatives, the $\mathrm{C}, \mathrm{N}$ linkage is essential for biological activity [4,5], several azomethine have been reported to possess remarkable antibacterial, antifungal, anticancer and antimalarial activities [6-9].

The derived compounds of Schiff base are of great importance nowadays. Mostly Schiff bases are crystalline and basic in nature. These are less expensive [10-12]. Ligand and its charged or neutral metal complexes can be easily synthesized. These metal complexes can be effectively used against cancer than the standard anti cancerous drug like cis-platin. Zn(II) complexes helps in faster healing of the wounds $[13,14]$. Schiff bases are soluble in variety of organic solvents except aqueous media at room temperature [15].

Biological activity probably conferred to them by the strong aromaticity of this ring system, which leads to great in vivo stability and generally, a lack of toxicity for higher vertebrates, including humans. Aside from these activities, Schiff bases also have other tremendous applications, they serves as dyes, agrochemicals, chemo sensor, catalyst, chemotherapeutic, anticorrosive, polymer [16-21]. Schiff bases have major concern in organic, inorganic, coordination, biochemistry and other material sciences [22].

*email: tariqm06@yahoo.co.uk; ktm7ro@yahoo.com 
As the continuation interest of our study of transition metal complexes, here we synthesis and characterization of new Schiff base ligand 3-hydroxybenzaldehyde with $p$-toluidine, and its complexes with $\mathrm{Ni}(\mathrm{II}), \mathrm{Fe}(\mathrm{II}), \mathrm{Co}(\mathrm{II}), \mathrm{Mn}(\mathrm{II}), \mathrm{Zn}$ (II) divalent metal ions. Structural confirmation of the synthesized Schiff base ligand characterization was done with different analytical techniques like single crystal X-ray analysis, ${ }^{1} \mathrm{H}-\mathrm{NMR}, \mathrm{FT}-\mathrm{IR}, \mathrm{AAS}, \mathrm{UV}$-visible spectroscopy and molar conductance. Biological evaluation of Schiff base ligand (L) and its transition metal complexes were also done by antifungal, antioxidant, and anti-inflammatory activities. Synthesized ligand and related complexes are said to demonstrate dynamic applications in the field of material sciences and medicine.

\section{Material and methods}

3-hydroxybenzaldehyde and $p$-toluidine were obtained from Sigma Aldrich. All the reagents, starting materials as well as solvents were purchased commercially and used without any further purification. Pure solvent like ethyl alcohol, n-hexane, ethyl acetate, chloroform, DMSO, DCM were used to check solubility of compounds at room temperature. Melting points were obtained from Gallenkamp apparatus. FT-IR was done on Perkin Elmer 1650 spectrophotometer at $4000-400 \mathrm{~cm}^{-1}$ in $\mathrm{KBr}$ pellets. AAS was done on AA320N atomic absorption spectrometer having 190-900 nm range. 6000 PC UV-visible spectrophotometer (190-1100 nm) was used for absorption measurements. Molar conductance measurements were calculated for $10^{-3} \mathrm{M}$ solution in DMSO at room temperature on METROHM 644 conductometer. Aluminum sheets layered with silica gel G-25-UV $\mathrm{UV}_{254}$ plate was used for TLC. Single crystal XRD method was used for structure determination of the Schiff base ligand (L) by suing Bruker SMART APEX II Diffractometer at 100(2) K temperature. BIOBASE oven (1150 W) was used for incubation and drying of crystals. ME-LEC-04P centrifuge apparatus of 4000 RPM, MEJA5003N digital weight balance having $0.001 \mathrm{~g}$ minimum reading and Raecho RVIS-1 spectrophotometer (325-1000 nm) was used for biological activities.

\section{Prepration of Schiff base ligand (L)}

Schiff base ligand (L) was synthesized by the reflux condensation reaction of 3-hydroxybenzaldehyde $(0.122 \mathrm{~g}, 1 \mathrm{mmole})$ along with amine component $p$-toluidine $(0.107 \mathrm{~g}, 1 \mathrm{mmole})$ using ethanol as solvent (Scheme 1) in addition of few drops of dimethylamine for $\mathrm{pH}$ stabilization and to prevent zwitterion formation. The reaction was carried out at $70-80{ }^{\circ} \mathrm{C}$ temperature with continuous stirring for about 5-6 hours into a $250 \mathrm{~mL}$ of round bottom flask. Brown pellet like crystals were obtained after 48 hours dried at room temperature. Distilled water was used for washing and product was recrystallized and dried at $25-27{ }^{\circ} \mathrm{C}$ giving yield of about $85 \%$ Shiny hazel brown needle like precipitates having melting point $113{ }^{\circ} \mathrm{C}$ and yield $85 \%$ were obtained.

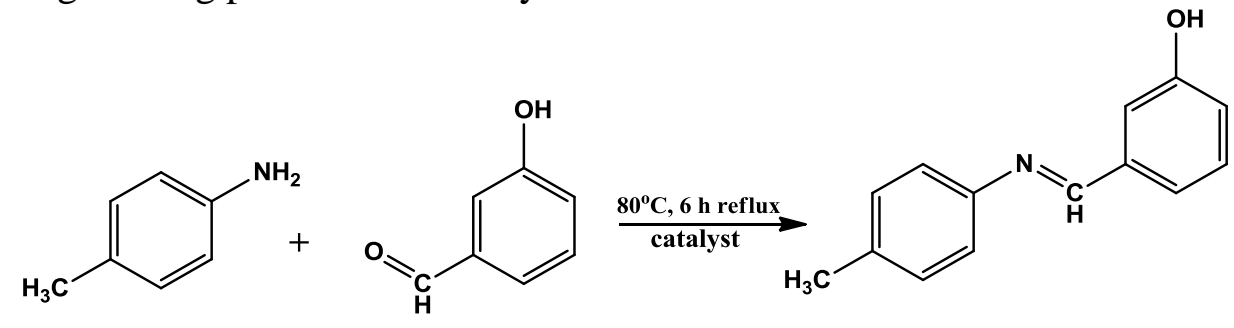

Scheme 1. Preparation of ligand (L)

\section{Synthesis of metal(II) Complexes}

\section{Synthesis of Ni-(L)}

$\mathrm{Ni}$ (II) sulfate salt (0.154 g, 1 mmole) was refluxed with Schiff base ligand (L) (0.422 g, 2 mmole) for $3-4 \mathrm{~h}$ at $50^{\circ} \mathrm{C}$ with continuous stirring in the presence of ethanol with 1-2 drops of dimethylamine for precipitation. The solution was filtered and dried at room temperature for $24 \mathrm{~h}$. Shiny light brown need like crystals were obtained, melting point $128^{\circ} \mathrm{C}$. 
Anal.: Calcd. for [Ni(L) $\left.)_{2} \mathrm{SO}_{4}\right]$, Calcd.: Ni, $10.18 \%$; Found: Ni, $9.83 \%$.

\section{Synthesis of Mn-(L)}

Complex was prepared by the reaction of $\mathrm{Mn}(\mathrm{II})$ acetate salt $(0.173 \mathrm{~g}, 1 \mathrm{mmole})$ with ligand (L) (0.422 g, 2 mmole) for 3-4 hours at $50{ }^{\circ} \mathrm{C}$ using ethyl alcohol as solvent and catalyst was used for obtaining shiny dark brown precipitate; Its melting point was $120^{\circ} \mathrm{C}$ with $40 \%$ yield of the crystals.

Anal.: Calcd. for $\left[\mathrm{Mn}(\mathrm{L})_{2}\left(\mathrm{CH}_{3}-\mathrm{COO}\right)_{2}\right]$, Calcd.: $\mathrm{Mn}, 9.23 \%$; Found: $\mathrm{Mn}, 8.94 \%$.

\section{Synthesis of $\mathbf{Z n - ( L )}$}

Metal complex was synthesized by heating 1:2 of the $\mathrm{Zn}(\mathrm{II})$ acetate salt $(0.183 \mathrm{~g}, 1 \mathrm{mmole})$ with the ligand (L) (0.422 g, 2 mmole) for 3-4 h till color changes. Shiny caramel brown precipitate with 52 $\%$ yield and $117^{\circ} \mathrm{C}$ melting point was measured.

Anal.: Calcd. for $\left[\mathrm{Zn}(\mathrm{L})_{2}\left(\mathrm{CH}_{3}-\mathrm{COO}\right)_{2}\right]$, Calcd.: $\mathrm{Zn}, 10.79 \%$; Found: $\mathrm{Zn}, 10.51 \%$.

\section{Synthesis of Co-(L)}

Co(II) acetate salt $(0.177 \mathrm{~g}, 1$ mmole) was refluxed with (L) (0.422 g, 2 mmole) for about

$4 \mathrm{~h}$ at suitable temperature to obtain the desired product. Shiny greenish brown precipitate with 43 $\%$ yield and $118^{\circ} \mathrm{C}$ melting point was measured.

Anal.: Calcd. for $\left[\mathrm{Co}(\mathrm{L})_{2}\left(\mathrm{CH}_{3}-\mathrm{COO}\right)_{2}\right]$, Calcd.: Co, $9.83 \%$; Found: $\mathrm{Co}, 9.55 \%$.

\section{Synthesis of Fe-(L)}

$\mathrm{Fe}$ (II) sulfate salt (0.151 g, 1 mmole) was reacted with Schiff base ligand (L) (0.422 g, 2 mmole) and heated in round bottom flask with $10-15 \mathrm{~mL}$ of solvent for at least $3 \mathrm{~h}$ and then filtered and dried in the oven to obtain shiny yellowish brown crystals with $22 \%$ yield and $125{ }^{\circ} \mathrm{C}$ melting point.

Anal.: Calcd. for [Fe(L) $\left.)_{2} \mathrm{SO}_{4}\right]$, Calcd.: $\mathrm{Fe}, 9.73 \%$; Found: $\mathrm{Fe}, 9.46 \%$.

The structure formulas of the metal complexes are shown in (Figure 1).

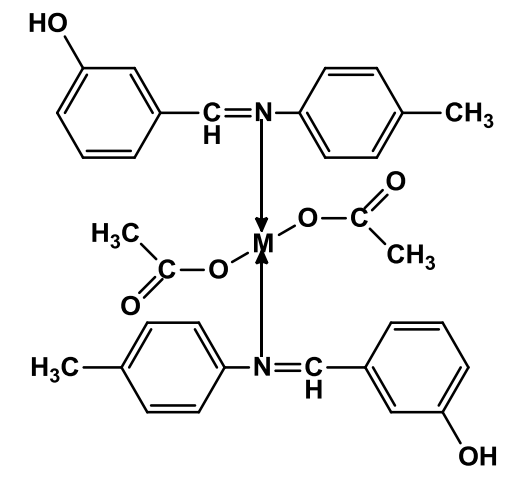

$\mathrm{M}=\mathrm{Mn}(\mathrm{II}), \mathrm{Co}(\mathrm{II}), \mathrm{Zn}(\mathrm{II})$

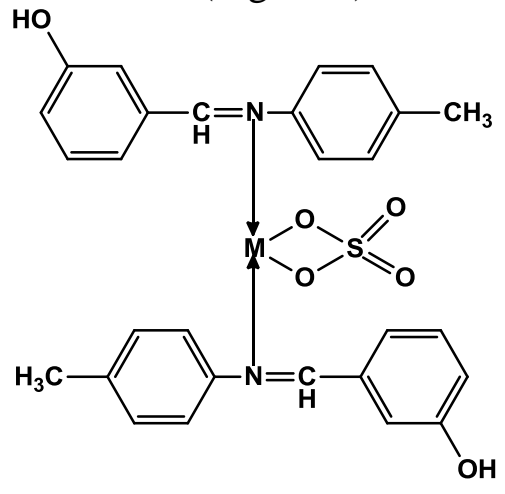

$\mathrm{M}=\mathbf{F e}(\mathrm{II}), \mathrm{Ni}(\mathrm{II})$

Figure 1. Structures of metal complexes

\section{Biological Activities}

\section{Antifungal assay}

Compounds were selected for antifungal activity (in vitro) by using agar tube dilution method [23] to find out the reactiveness of ligand and metal complexes against Miconazole used as standard drug. Compounds were tested against Candida albicans and Candida glabrata fungi, (Fig. 2). Each sample was prepared $200 \mathrm{mg} / \mathrm{mL}$ in DMSO solvent. Activity was done on 96 welled plate which were incubated at $27{ }^{\circ} \mathrm{C}\left(28 \pm 1{ }^{\circ} \mathrm{C}\right)$ for about 168 hours and percentage inhibition of the standard and synthesized compounds were calculated [24]. 


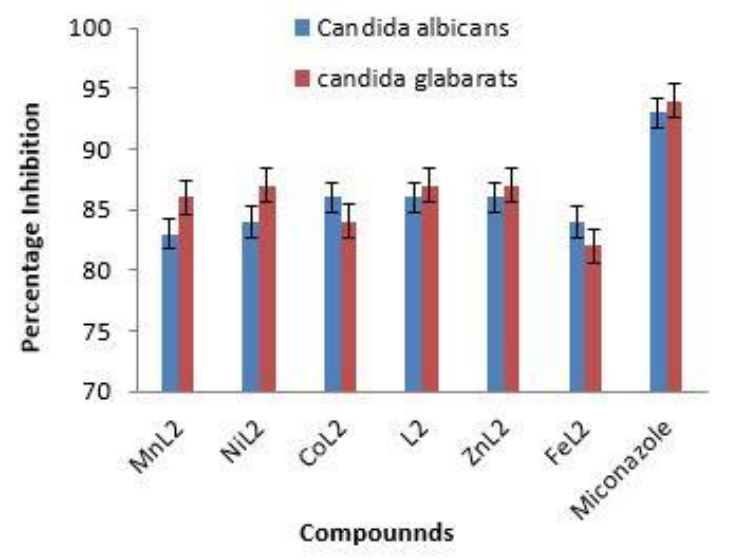

Figure 2. Antifungal activity of synthesized compounds

(L, Mn-L, Ni-L, Co-L, Zn-L,Fe-L); Antifungal activity of synthesized compounds $(200 \mathrm{mg} / \mathrm{mL})$ by the Agar tube dilution protocol and

Miconazole (200 mg mL) was used as standard

\section{In vivo anti-inflammatory activity}

\section{a) Experimental animal}

Albino male SD rats having weight about 100-150 g were used to carried out the in vivo antiinflammatory screening of ligand (L) and metal ions complexes using Carrageenan as standard drug. Animals were kept in a lab having free contact with pathogens, at room temperature $\left(25 \pm 5{ }^{\circ} \mathrm{C}\right)$, moisture $(50 \pm 10 \%)$ with accessibility of distilled water to the animals during the experimental handling. All the measures were ratified by the IEC (Institutional ethical committee) PUIC (Punjab University, Institute of Chemistry, Lahore) and international precautions were also kept in mind to create healthy atmosphere for rats.

\section{b) Paw Edema Method (Procedure)}

Rats weighing 150-200 g were used for the experimental work and they were distributed in three sections and all rats were deprived of food overnight. Dose of $100 \mu \mathrm{L}$ of the test drug (synthesized) was given orally to the test group rats and in case of control group $100 \mu \mathrm{L}$ distilled water and in case of standard group diclofenac sodium $1 \mathrm{mg}$ was given orally. After $30 \mathrm{~min}$ of the orally given dose about $0.1 \mathrm{~mL}$ of Carrageenan injected into sub planter surface of rat's hind paw. Paw volume was note dinstantly after administration of Carrageenan at 0.0, 60, 120, 180 and $240 \mathrm{~min}$ time period, respectively (Fig. 3), (Fig. 4). Row 1, 3, 5 shows sub planter sites of rat's paw indicating redness or inflammation which gradually decreases from left to right site from $0 \mathrm{~h}$ to $3 \mathrm{~h}$ time. Similarly row 2 (Schiff base ligand), 4(Co-L complex), 6(Diclofenac Sodium; standard drug) shows level of swelling decreased with passage of time, while series 4 in case of Co(II) complex shows maximum antiinflammatory activity [25]. Percentage protection [26] measured as follow:

$$
\text { Percentage Inhibition }=\left(1-\mathrm{V}_{\mathrm{t}} / \mathrm{V}_{\mathrm{c}}\right) \times 100
$$

where; $\mathrm{V}_{\mathrm{t}}$ corresponds to increase in the paw volume of test sample and $\mathrm{V}_{\mathrm{c}}$ increase in paw volume of control. 


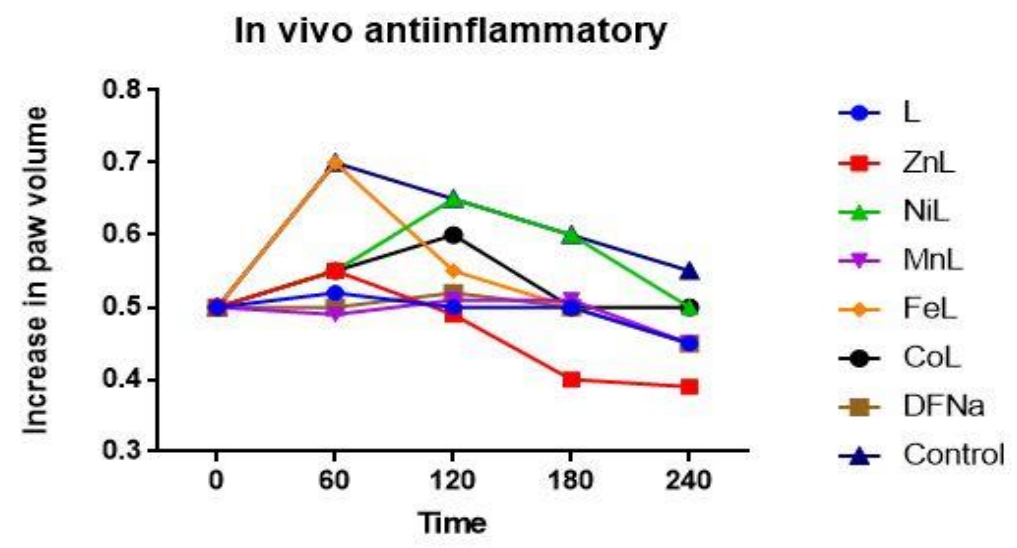

Figure 3. In-vivo time dependent anti-inflammatory assay for

(L, Mn-L, Ni-L, Co- L, Zn-L, Fe-L) in SD rats by using induced paw edema method using Diclofenac Sodium $(10 \mathrm{mg} / \mathrm{kg})$ as standard

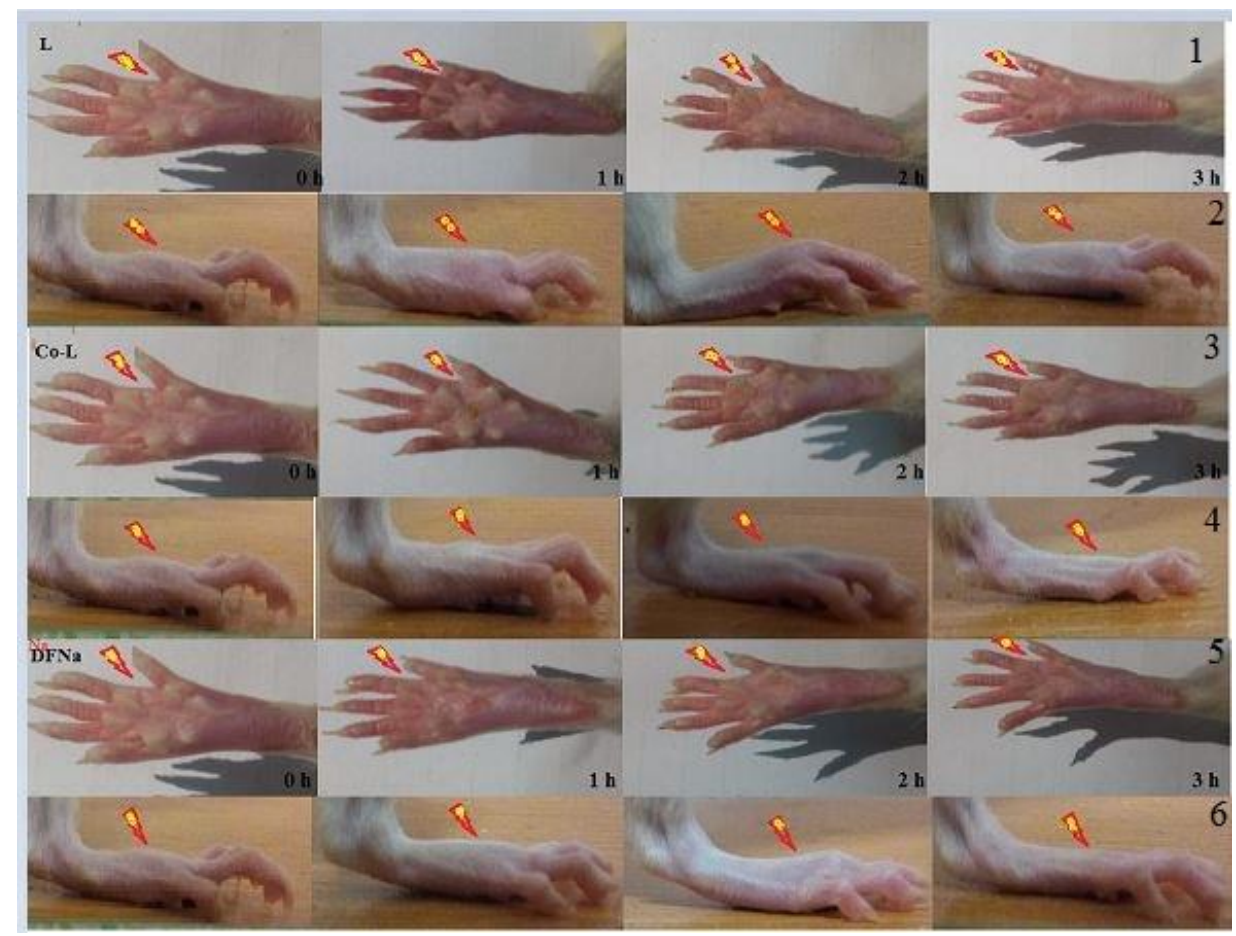

Fig. 4. Pathological studies of (L), Co-L, Diclofenac Sodium and Carrageenan were used to induce inflammation in the paw of SD rats. Synthesized drugs $100 \mathrm{mg} / \mathrm{kg}$ were administrated orally

\section{In vitro anti-inflammatory assay}

(By Protein Denaturation Heat Induced Method)

Carefully separate egg albumin in a beaker and vigorously stirred it for about $10 \mathrm{~min}$. Make ethanolic solution of the $0.004 \mathrm{~g}$ of the synthesized compounds and from this make dilutions of about 400, 200, 100, 50 and 25 ppm. Make PBS (phosphate buffered saline) solution in distilled water and maintain $p \mathrm{H}$ of 6.4 by adding 1-2 drops of $1 \mathrm{M} \mathrm{HCl}$. $1 \mathrm{M}$ Diclofenac sodium solution in $100 \mathrm{~mL}$ 
distilled water serve as standard. Add $0.2 \mathrm{~mL}$ of the egg albumin in each bottle by micro pipette, 2.8 $\mathrm{mL}$ of the PBS solution. $2.8 \mathrm{~mL}$ of PBS sol and $2 \mathrm{~mL}$ of sample solution; $2 \mathrm{~mL}$ of the ethanol, $0.2 \mathrm{~mL}$ of egg albumin and $2.8 \mathrm{~mL}$ of PBS solution used as control solution. Then incubate all sample bottles firstly at $37^{\circ} \mathrm{C}$ for about $15 \mathrm{~min}$ and then for $5 \mathrm{~min}$ at $60{ }^{\circ} \mathrm{C}$ temperature [27]. Carefully note absorbance 15 min time interval. Calculate percentage inhibition of the sample and standard as:

\section{Percentage Inhibition $=\left(1-\mathrm{V}_{\mathrm{t}} / \mathrm{V}_{\mathrm{c}}\right) \times 100$}

where: $\mathrm{V}_{\mathrm{t}}$ is for absorbance of the test sample and $\mathrm{V}_{\mathrm{c}}$ shows absorbance of control moiety, (Fig. 5), (Table 1).

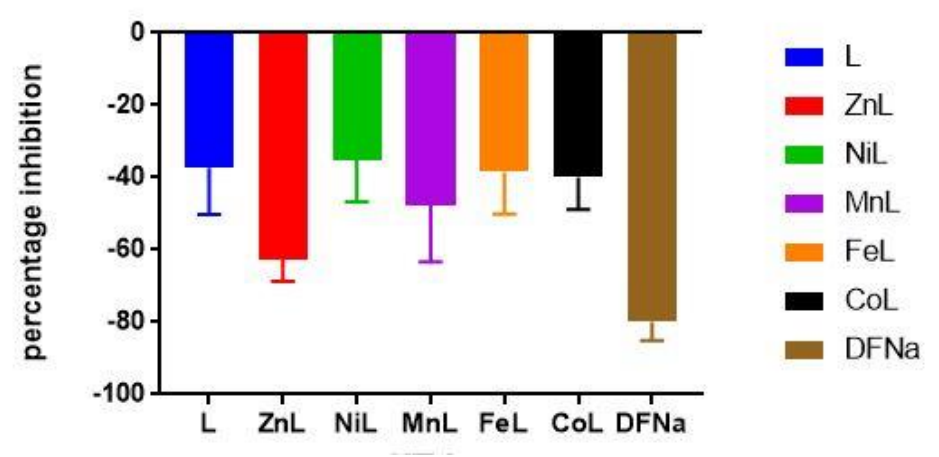

Fig. 5. Percentage inhibition of in-vitro anti-inflammatory assay for (L, Mn-L, Ni-L, Co-L, Zn-L, Fe-L) by heat induced protein denaturation method. Graph represents the percentage inhibition at (25-400 ppm) concentration

Table 1. $\mathrm{IC}_{50}{ }^{\mathrm{a})}$ values of the synthesized compounds With diclofenac sodium

\begin{tabular}{|l|l|l|}
\hline Sr. No. & Compounds & IC $_{\mathbf{5 0}} \mathbf{a}^{\mathbf{)}}$ \\
\hline 1. & Ligand (L) & 3.46 \\
\hline 2. & Mn-L & 3.34 \\
\hline 3. & Zn-L & 6.1 \\
\hline 4. & Co-L & 4.23 \\
\hline 5. & Ni-L & 3.5 \\
\hline 6. & Fe-L & 3.19 \\
\hline 7. & DFNa & 8.18 \\
\hline
\end{tabular}

\section{Antioxidant activity (in vitro) DDPH assay}

Trolox stock solution was prepared by dissolving $0.005 \mathrm{~g}$ of Trolox in ethanol and raised the volume up to $10 \mathrm{~mL}$. The concentration of this solution was $2000 \mathrm{mM}$. From this stock solution 1000 $\mathrm{mM}, 500 \mathrm{mM}, 250 \mathrm{mM}, 125 \mathrm{mM}, 62.5 \mathrm{mM}, 31.25 \mathrm{mM}, 15.62 \mathrm{mM}, 7.81 \mathrm{mM}, 3.9 \mathrm{mM}$ and $1.95 \mathrm{mM}$ Trolox dilutions were made by taking one $\mathrm{ml}$ of ethanol this will give $1000 \mathrm{mM}$ solution. Then take one $\mathrm{ml}$ of $1000 \mathrm{mM}$ solution and add $1 \mathrm{~mL}$ of ethanol this will give $500 \mathrm{~mL}$ then diluted further solution by applying same rule.

Trolox was used as standard for in vitro antioxidant assay [28]. Now add $1.85 \mathrm{~mL}$ of the DPPH $(0.05 \mathrm{mM})$ solution in every bottle. Note that for every experiment freshly prepared and preserved in dark solution of Trolox was used.

In the exactly same way prepare synthesized sample $(0.005 \mathrm{~g})$ stock solutions ranging from $2000-$ $1.95 \mathrm{mM}$ by using ethanol further dilute them in a brown bottle by adding $1 \mathrm{~mL}$ of stock solution and 
$1.85 \mathrm{~mL}$ of the $D P P H$. Note the absorbance at $15,30,45,60,120 \mathrm{~min}$ in a spectrophotometer for sample, ligand (L) and its metal ions complexes and standard (Trolox) solution.

Calculate percentage inhibition by the formula:

$$
\text { Percentage Inhibition }=\left(1-\mathrm{A}_{\mathrm{s}} / \mathrm{A}_{\mathrm{c}}\right) \times 100
$$

where: $A_{s}$ shows absorbance of the synthesized sample, $A_{c}$ is for absorbance of the control sample, Control contain $1 \mathrm{~mL}$ of ethanol and $1.85 \mathrm{~mL}$ of the $D P P H$. From percentage inhibition values calculate $\mathrm{IC}_{50}$ values [29], (Table 2).

Table 2. In vitro antioxidant activity ic 50 values of the Synthesized compounds

\begin{tabular}{|c|c|c|c|c|c|}
\hline \multirow{2}{*}{ Compound } & \multicolumn{5}{|c|}{ Time (min) } \\
\cline { 2 - 6 } & $\mathbf{1 5}$ & $\mathbf{3 0}$ & $\mathbf{4 5}$ & $\mathbf{6 0}$ & $\mathbf{1 2 0}$ \\
\hline Ligand (L) & 25.74 & 23.02 & 20.37 & 14.29 & 13.11 \\
\hline Mn-L & 8.324 & 8.06 & 7.43 & 7.17 & 6.53 \\
\hline $\mathrm{Zn}-\mathrm{L}$ & 4.04 & 19.22 & 19.57 & 17.84 & 16.25 \\
\hline Co-L & 15.48 & 15.65 & 16.02 & 27.71 & 55.43 \\
\hline Ni-L & 28.14 & 22.89 & 19.08 & 16.79 & 12.81 \\
\hline Fe-L & -36.42 & 4.09 & 13.35 & 12.89 & 6.9 \\
\hline $\begin{array}{c}\text { Trolox } \\
\text { (Standard) }\end{array}$ & 2.35 & 2.33 & 2.34 & 2.32 & 2.30 \\
\hline
\end{tabular}

\section{Results and discussions}

\section{FT-IR}

The metal-ligand bond was verified by comparing the IR spectrum of the Schiff base ligand with metal (II) complexes. Absence of band characteristics at $1550 \mathrm{~cm}^{-1}$ for primary amine and $1720 \mathrm{~cm}^{-1}$ for aldehyde and appearance of sharp band at $1620 \mathrm{~cm}^{-1}$ indicates the azomethine group $(-\mathrm{CH}=\mathrm{N}-)$. Spectral values of the prepared samples are given below (Table 3) [30, 31]. The FT-IR spectra predicted all the absorption bands of the Schiff base ligand (L) and some new bands at specific frequency confirmed the modes of absorption and the coordination of the ligand (L) with the metal ions through azomethine nitrogen and oxygen (carboxyl, sulfate). The phenolic oxygen is not involved in coordination. In the complexes $\mathrm{Mn}$ (II), $\mathrm{Co}(\mathrm{II}), \mathrm{Zn}$ (II) two bands appeared in the region 1658-1651 $\mathrm{cm}^{-1}$ ( $v$-asymmetry) and $1419-1396 \mathrm{~cm}^{-1}$ ( $v$-symmetry) which attribute the carboxylate part in the acetate group and also suggest that they are responsible for the consisting of unidentate coordination site with the metal ion due to the value of differences between asymmetry and symmetry was greater than $200 \mathrm{~cm}^{-1}\left(\Delta v \geq 200 \mathrm{~cm}^{-1}\right)$. The far IR spectra of the complexes show weak bands in the region $466-434 \mathrm{~cm}^{-1}$ and $512-475 \mathrm{~cm}^{-1}$ corresponding to $v(\mathrm{M}-\mathrm{N})$ and $v(\mathrm{M}-\mathrm{O})$ vibrations, respectively and other absorption bands were no appreciable change in the ligand (L) and metal complexes [32].

Table 3. FT-IR data of the synthesized compounds

\begin{tabular}{|l|l|l|l|l|l|}
\hline \multicolumn{6}{|c|}{ Vibrational frequency $\left(\mathbf{c m}^{-\mathbf{1}}\right)$} \\
\hline Sr. No. & Compounds & $v(\mathrm{C}=\mathrm{N})$ & $\begin{array}{l}v(\mathrm{OH})- \\
\text { phenol }\end{array}$ & $v(\mathrm{M}-\mathrm{N})$ & $v(\mathrm{Ph}-\mathrm{O})$ \\
\hline 1. & L & 1620 & 3345 & - & 1232 \\
\hline 2. & Ni-L & 1591 & 3346 & 466 & 1220 \\
\hline 3. & Mn-L & 1615 & 3348 & 460 & 1209 \\
\hline 4. & Co-L & 1614 & 3350 & 462 & 1214 \\
\hline 5. & Zn-L & 1612 & 3344 & 464 & 1216 \\
\hline 6. & Fe-L & 1613 & 3347 & 434 & 1240 \\
\hline
\end{tabular}




\section{${ }^{1}$ H-NMR}

Schiff base ligand (L) $\mathrm{C}_{14} \mathrm{H}_{13} \mathrm{NO}$ structure was confirmed by the proton ${ }^{1} \mathrm{H}-\mathrm{NMR}$ spectroscopy. Peaks were detailed on BRUKER $300 \mathrm{MHz}$ instrument by using $\mathrm{CDCl}_{3}$ as solvent. One singlet peak was observed for $\mathrm{CH}_{3}$ group, one broad peak at $\delta 5.025 \mathrm{ppm}$ shows residual $\mathrm{NH}_{2}$, aromatic benzene ring protons were shown in the form of multiplet at $\delta 7.562-6.743 \mathrm{ppm}$, one more deshielded singlet was recorded at $\delta 8.404 \mathrm{ppm}$ for $(-\mathrm{CH}=\mathrm{N}-)$ proton, one singlet was observed at $\delta 9.890 \mathrm{ppm}$ for $\mathrm{OH}$ group $[33,34]$.

\section{Single crystal X-ray analysis}

For single crystal X-ray analysis, Bruker SMART APEX II Diffractometer fortified with CCD detector was used [35]. Single crystal of complex was grown by evaporation method with a volume ratio of 3:1 of $\mathrm{CH}_{3} \mathrm{CN}: \mathrm{CH}_{3} \mathrm{OH}$. The room temperature single crystal $\mathrm{X}$-ray experiments were conducted on a (Bruker Smart APEX) Single Crystal Diffractometer equipped with graphite monochromatized Mo-K $\alpha$ radiation. Single Orange plate like ligand having formula of $\mathrm{C}_{14} \mathrm{H}_{13} \mathrm{NO}$ with single crystal was measured with $\lambda=1.54178 \AA$ for $\mathrm{X}$-ray intensity data by using Bruker SAINT Software package [36], (Table 4), (Fig. 6).

Table 4. Single Crystal X-ray analysis data of Schiff base ligand (L)

\begin{tabular}{|c|c|}
\hline Identification code & $\mathrm{L}$ \\
\hline Chemical formula & $\mathrm{C}_{14} \mathrm{H}_{13} \mathrm{NO}$ \\
\hline Formula weight & $211 \mathrm{~g} / \mathrm{mol}$ \\
\hline Temperature & $100(2) \mathrm{K}$ \\
\hline Wavelength & $1.54178 \AA$ \\
\hline Crystal size & $0.080 \times 0.160 \times 0.180 \mathrm{~mm}$ \\
\hline Crystal habit & Orange plate \\
\hline Space group & P $121 / n$ \\
\hline Unit cell dimension & $\begin{array}{l}\mathrm{a}=13.9385(6) \AA \\
\mathrm{b}=16.8693(7) \AA \\
\mathrm{c}=15.3311(7) \AA\end{array}$ \\
\hline Volume & $3544.7(3) \AA^{3} \mathrm{Z} 4$ \\
\hline Density (calculated) & $1.255 \mathrm{~g} / \mathrm{cm}^{3}$ \\
\hline Absorption coefficient & $0.659 \mathrm{~mm}^{-1}$ \\
\hline$\alpha, \gamma$ & $90^{\circ}$ \\
\hline$\beta$ & $100.481(2)^{\circ}$ \\
\hline
\end{tabular}



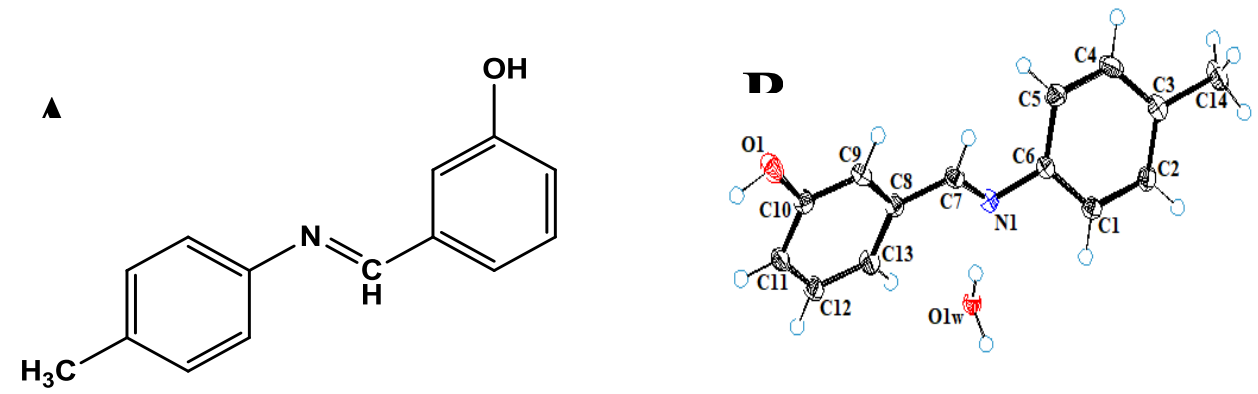

Figure 6. (A) Proposed structure of the synthesized ligand (L);

(B) ORTEP view of $\mathrm{FeL}_{2}$ drawn at $50 \%$ probability level and solvent molecules are omitted for clarity.

\section{UV-visible spectroscopy}

UV-visible spectra for synthesized Schiff base ligand (L) and complexes with $\mathrm{Ni}(\mathrm{II}), \mathrm{Co}(\mathrm{II})$, $\mathrm{Mn}(\mathrm{II}), \mathrm{Zn}(\mathrm{II}), \mathrm{Fe}(\mathrm{II})$ metal ions were determined in the presence of the ethanol. $\lambda_{\max }$ for ligand (L) was observed at $380 \mathrm{~nm}$ that predicts the intramolecular charge transfer interaction and $\pi-\pi^{*}$ electronic transitions for $(-\mathrm{CH}=\mathrm{N}-)$ azomethine group. Ligand $\lambda_{\max }$ absorption peak moves to the lower wavelength, complexes range was from 360-335 $\mathrm{nm}$.

The elemental analysis proposes the stoichiometry to be 1:2 (metal / ligand).

The geometry of metal complexes was also confirmed on the basis of data collected through electronic absorption spectra and magnetic moment [37]. The electronic spectra and magnetic moment values suggested their tetrahedral geometry (Table 5).

\section{Molar conductance}

Molar conductance values of the synthesized ligand (L) and its metal ions complexes were calculated in the DMSO $\left(10^{-3} \mathrm{M}\right.$ solutions) at $27{ }^{\circ} \mathrm{C}$ by conductometer. Values of the measured molar conductance were in the range of $16-24 \Omega^{-1} \cdot \mathrm{cm}^{2} \cdot \mathrm{mol}^{-1}$. From the obtained data non-electrolyte nature of the synthesized compounds was predicted (Table 5) [38, 39].

Table 5.UV-visible and molar conductance values

\begin{tabular}{|c|c|c|c|c|c|}
\hline Sr. No. & Sample & $\begin{array}{c}\lambda_{\max } \\
\left(\mathbf{c m}^{-1}\right)\end{array}$ & Tentative assignment & $\begin{array}{c}\text { B.M. } \\
\left(\boldsymbol{\mu}_{\text {eff }}\right.\end{array}$ & $\begin{array}{c}\text { Conductance } \\
\left(\mathbf{\Omega}^{-1} \cdot \mathbf{c m}^{2} \cdot \mathbf{m o l}^{-1}\right)\end{array}$ \\
\hline 1. & $\mathrm{~L}$ & 26315 & $\pi-\pi^{*}$ & - & - \\
\hline 2. & Zn-L & 27472 & Ligand $\rightarrow$ metal & Diamagnetic & 23.4 \\
\hline 3. & Mn-L & $\begin{array}{c}26246 \\
24096\end{array}$ & $\begin{array}{c}\mathrm{n} \rightarrow \pi^{*} \\
\mathrm{CT}\end{array}$ & 5.61 & 16.1 \\
\hline 4. & Co-L & 16920 & ${ }^{4} \mathrm{~A}_{2}(\mathrm{~F}) \rightarrow{ }^{4} \mathrm{~T}_{1}(\mathrm{P})$ & 4.13 & 17.1 \\
\hline 5. & Fe-L & 12970 & ${ }^{5} \mathrm{E} \rightarrow{ }^{5} \mathrm{~T}_{2}$ & 5.22 & 23.8 \\
\hline 6. & Ni-L & 15260 & ${ }^{3} \mathrm{~T}_{1}(\mathrm{~F}) \rightarrow{ }^{3} \mathrm{~T}_{1}(\mathrm{P})$ & 3.81 & 18.7 \\
\hline
\end{tabular}

\section{Conclusions}

In this piece of work a new Schiff base ligand (L) with molecular formula $\mathrm{C}_{14} \mathrm{H}_{13} \mathrm{NO}$ was prepared; its purity confirms by ${ }^{1} \mathrm{H}-\mathrm{NMR}$ and its divalent metal ions complexes that show biological activities. Single crystal X-ray analysis shows orange plate like monoclinic crystal structure of ligand. Molar conductance values show non-electrolyte behavior of the complexes. Compounds are 
comparatively active against antifungal assay, in-vivo and in-vitro results of anti-inflammatory activity that metal complexes and ligand (L) are more reactive than standard. In-vitro antioxidant out comes reveals that compounds are active at lower concentration. The activities of all the complexes obtained were found to be moderate even though higher concentrations were applied. This may be due to the bulkiness of the molecule with a complicated structure which in turn restricts their mobility to the target cell or active site although all the complexes were obtained as a monomeric and fourcoordinated metal(II).

Acknowledgement. We are highly thankful to HEC (Higher Education Commission), Government of Pakistan for providing ASIG (Access to Scientific Instrumentation Grant) for research work and also to the Institute of Chemistry, University of the Punjab, Lahore, Pakistan for providing lab facilities during the research work.

\section{References}

1.SCHIFF, H., Mittheilungen aus dem Universitätslaboratorium in Pisa: eine neue Reihe organischer Basen, Justus Liebigs Annalen der Chemie., 131, 1864, 118-119.

2.ARUN, T., PACKIANATHAN, S., MALARVIZHI, M., ANTONY, R., RAMAN, N., Bio-relevant complexes of novel $\mathrm{N}_{2} \mathrm{O}_{2}$ type heterocyclic ligand: Synthesis, structural elucidation, biological evaluation and docking studies, J.Photochem.Photobiol.B: Biol., 149, 2015, 93-102.

3.MORADINIA, E., MANSOURNIA, M., ARAMESH, B. Z., BORDBAR, A. K., New transition metal complexes of 9, 10-phenanthrenequinone $p$-toluyl hydrazone Schiff base: Synthesis, spectroscopy, DNA and HSA interactions, antimicrobial, DFT and docking studies, Appl.Organometall.Chem., 33, 2019, 4893-4914.

4.AVAJI, P. G., KUMAR, C. V., PATIL, S. A., SHIVANANDA, K. N., NAGARAJU, C., Synthesis, spectral characterization, in-vitro microbiological evaluation and cytotoxic activities of novel macrocyclic bis hydrazone, Eur.J.Med.Chem., 44, 2009, 3552-3559.

5.MUMTAZ, A., MAHMUD, T., ELSEGOOD, M. R., WEAVER, G. W., Synthesis, Characterization and in vitro Biological Evaluation of a New Schiff Base Derived from Drug and its Complexes with Transition Metal Ions, Rev.Chim., 69, 2018, 1678-1681.

6.LOISELEUR, O., Natural products in the discovery of agrochemicals, CHIMIA, Int.J. for Chem., 71(12), 2017, 810-822.

7.DA, S. C. M., DA, S. D. L., MODOLO, L. V., ALVES, R. B., DE, RESENDE, M. A., MARTINS, C. V., DE, F. Â., Schiff bases: A short review of their antimicrobial activities, J.Adv.Res., 2, 2011, 1-8. 8.DESAI, S. B., DESAI, P. B., DESAI, K. R., Synthesis of some Schiff bases, thiazolidinones and azetidinones derived from 2, 6-diaminobenzo [1, 2-d: 4, 5-d'] bisthiazole and their anticancer activities, Heterocyclic Commun., 7, 2001, 83-90.

9.PINTO, D. J., ORWAT, M. J., KOCH, S., ROSSI, K. A., ALEXANDER, R. S., SMALLWOOD, A., WONG, P. C., RENDINA, A. R., LUETTGEN, J. M., KNABB, R. M., HE, K., Discovery of 1-(4methoxyphenyl)-7-oxo-6-(4-(2-oxopiperidin-1-yl) phenyl)-4, 5, 6, 7-tetrahydro-1 H-pyrazolo [3, 4-c] pyridine-3-carboxamide (Apixaban, BMS-562247), a highly potent, selective, efficacious, and orally bioavailable inhibitor of blood coagulation factor Xa, J.Med.Chem., 50, 2007, 5339-5356.

10.KUMAR, S., DHAR, D. N., SAXENA, P. N., Applications of metal complexes of Schiff bases-A review, J.Sci.Ind.Res., 68, 2009, 181-187.

11.PALCZEWSKI, K., KUMASAKA, T., HORI, T., BEHNKE, C. A., MOTOSHIMA, H., FOX, B. A., LE, T. I., TELLER, D. C., OKADA, T., STENKAMP, R. E., YAMAMOTO, M., MIYANO M., Crystal structure of Rhodopsin: A G Protein-Coupled Receptor, Science, 289, 2000, 739-745.

12.ROMERO, C. I., SALASSA, L., SADLER, P. J., The contrasting activity of iodido versus chlorido ruthenium and osmium arene azo-and imino-pyridine anticancer complexes: control of cell selectivity, cross-resistance, p53 dependence, J.Med.Chem., 56, 2013, 1291-1300. 
13.GATELY, D. P., HOWELL, S. B., Cellular accumulation of the anticancer agent cisplatin: a review, British J.Cancer., 67, 1993, 1171-1176.

14.WANG, H., YUAN, H., LI, S., LI, Z., JIANG, M., Synthesis, antimicrobial activity of Schiff base compounds of cinnamaldehyde and amino acids, Bioorg.Med.Chem.Lett., 26(3), 2016, 809-813.

15.SINAN, M., PANDA, M., BANERJEE, P., SHINISHA, C. B., SUNOJ, R. B., GOSWAMI, S., Synthesis of Azoaromatic Dyes via Redox Driven C- N Bond Fusion, Org.Lett., 11, 2009 Aug, 32183221.

16.SUVARAPU, L. N., SEO, Y. K., BAEK, S. O., AMMIREDDY, V. R., Review on analytical and biological applications of hydrazones and their metal complexes, J.Chem., 9, 2012, 1288-1304.

17.KUMAR, A., LAYEK, S., AGRAHARI, B., KUJUR, S., PATHAK, D. D., Graphene Oxide Immobilized Copper (II) Schiff Base Complex [GO@ AF-SB-Cu]: A Versatile Catalyst for Chan-Lam Coupling Reaction, Chem.Select., 4, 2019, 1337-1345.

18.AMBIKA, S., MANOJKUMAR, Y., ARUNACHALAM, S., GOWDHAMI, B., SUNDARAM, K. K., SOLOMON, R. V., VENUVANALINGAM, P., AKBARSHA, M. A., SUNDARARAMAN, M., Biomolecular interaction, anti-cancer and anti-angiogenic properties of cobalt(III) Schiff base complexes, Scien.Reports, 9, 2019, 1-14.

19.FREIRE, C., NUNES, M., PEREIRA, C., FERNANDES, D. M., PEIXOTO, A. F., ROCHA, M., Metallo (salen) complexes as versatile building blocks for the fabrication of molecular materials and devices with tuned properties, Coord.Chem.Rev., 394, 2019, 104-134.

20.NEGM, N. A., GHUIBA, F. M., MAHMOUD, S. A., TAWFIK, S. M., Biocidal and anti-corrosive activities of benzoimidazol-3-ium cationic Schiff base surfactants, Eng. Life Sci., 11, 2011, 496-510.

21.XIANG, T., LIU, X., YI, P., GUO, M., CHEN, Y., WESDEMIOTIS, C., XU, J., PANG, Y., Schiff base polymers derived from 2,5-diformylfuran, Polym.Int., 62, 2013,1517-1523.

22.KAJAL, A., BALA, S., KAMBOJ, S., SHARMA, N., SAINI, V., Schiff bases: a versatile pharmacophore, J.Catalysts, 2013, 2013, 1-15.

23.BHARTI, S. K., NATH, G., TILAK, R., SINGH, S. K., Synthesis, anti-bacterial and anti-fungal activities of some novel Schiff bases containing 2,4-disubstituted thiazole ring, Eur.J.Med.Chem., 45, 2010, 651-660.

24.BELAID, S., LANDREAU, A., DJEBBAR, S., BENALI, B. O., BOUET, G., BOUCHARA, J. P., Synthesis, characterization and antifungal activity of a series of manganese(II) and copper(II) complexes with ligands derived from reduced $\mathrm{N}, \mathrm{N}^{\prime}-\mathrm{O}-$ phenylenebis (salicylideneimine), J.Inorg.Biochem., 102, 2008, 63-69.

25.BAWA, S., KUMAR, S., Synthesis of Schiff's bases of 8-methyl-tetrazolo[1,5-a] quinoline as potential anti-inflammatory and antimicrobial agents, Indian J.Chem., 48, 2009, 142-145.

26.VAZZANA, I., TERRANOVA, E., MATTIOLI, F., SPARATORE, F., Aromatic Schiff bases and 2,3-disubstituted-1,3-thiazolidin-4-one derivatives as anti-inflammatory agents, Arkivoc, 364, 2004, 364-374.

27.MURTAZA, S., AKHTAR, M. S., KANWAL, F., ABBAS, A., ASHIQ, S., SHAMIM, S., Synthesis and biological evaluation of schiff bases of 4-aminophenazone as an anti-inflammatory, analgesic and antipyretic agent, J.Saudi Chem.Soc., 21, 2017, 359-372.

28.MUlLER, L., FRÖHLICH, K., BÖHM, V., Comparative antioxidant activities of carotenoids measured by ferric reducing antioxidant power (FRAP), ABTS bleaching assay ( $\alpha$ TEAC), DPPH assay and peroxyl radical scavenging assay, Food Chem., 129, 2011, 139-148.

29.MUMTAZ, A., MAHMUD, T., ELSEGOOD, M., WEAVER, G., BRATU, G., MITU, L., Synthesis, Characterization and Biological Evaluation of Schiff Base ( $N$-4-(thiophene-2-ylmethyleneamino)-2,6-dimethylpyrimidine-4-yl)benzenesulfonamide and its Complexes with $\mathrm{Cu}(\mathrm{II})$, $\mathrm{Ni}(\mathrm{II}), \mathrm{Co}(\mathrm{II}), \mathrm{Fe}(\mathrm{II}), \mathrm{Mn}(\mathrm{II}), \mathrm{Zn}$ (II) Ions, Rev.Chim., 71, 2020, 206-211.

30.GABER, M., EL, W. N., EL, B. K., Hafez, S., Chromone Schiff base complexes: synthesis, structural elucidation, molecular modeling, antitumor, antimicrobial, and DNA studies of $\mathrm{Co}(\mathrm{II})$, $\mathrm{Ni}(\mathrm{II})$, and $\mathrm{Cu}(\mathrm{II})$ complexes, J.Iran.Chem.Soc., 16, 2019, 169-182. 
31.CHEN, Y., MI, Y., SUN, X., ZHANG, J., LI, Q., JI, N., GUO, Z., Novel Inulin Derivatives Modified with Schiff Bases: Synthesis, Characterization, and Antifungal Activity, Polymers, 6, 2019, 998-1010.

32.GUPTA, L. K., BANSAL, U., CHANDRA, S., Spectroscopic and physicochemical studies on nickel(II) complexes of isatin-3,2'-quinolyl-hydrazones and their adducts, Spectrochim.Acta Part A: Mol.Biomol.,Spectr., 66, 2007, 972-975.

33.PANDEY, A., ASTHANA, S. K., PRAKASH, A., ROY, J. K., TIWARI, I., UPADHYAY, K. K., A selective hydrolytic and restructuring approach through a Schiff base design on a coumarin platform for "turn-on" fluorogenic sensing of $\mathrm{Zn}^{2+}$ ", Dalton Trans., 48, 2019, 2068-2076.

34.FUN, H. K., PATIL, P.S., RAO, J. N., KALLURAYA, B., CHANTRAPROMMA S., Chloro-N'-[(Z)-4-nitrobenzylidene] benzohydrazide monohydrate, Acta Cryst.Section E: Struc.Rep.Online, 64, 2008, 1707-1717.

35.HOSSAIN, M. S., ZAKARIA, C. M., KUDRAT., E. Z. M., ZAMAN, B., Synthesis, spectral and thermal characterization of $\mathrm{Cu}(\mathrm{II})$ complexes with two new Schiff base ligand towards potential biological application, Der Chem. Sinica, 8, 2017, 380-392.

36.DAS, M., KUNDU, B. K., TIWARI, R., MANDAL, P., NAYAK, D., GANGULY, R., MUKHOPADHYAY, S., Investigation on chemical protease, nuclease and catecholase activity of two copper complexes with flexidentate Schiff base ligands, Inorg.Chim.Acta, 469, 2018, 111-122.

37.ISSA, R. M., KHEDR, A. M., RIZK, H. F., UV-vis, IR and 1H NMR spectroscopic studies of some Schiff bases derivatives of 4-aminoantipyrine, Spectrochim.Acta Part A: Mol.Biomol.,Spectr., 62, 2005, 621-629.

38.MOUNIKA, K., PRAGATHI, A., GYANAKUMARI, C., Synthesis characterization and biological activity of a Schiff base derived from 3-ethoxy salicylaldehyde and 2-amino benzoic acid and its transition metal complexes, J.Sci.Res., 2, 2010, 513-524.

39.ARANHA, P.E., SANTOS, D.M.P., ROMERA, S., DOCKAL, E.R., Synthesis, characterization, and spectroscopic studies of tetradentate Schiff base chromium(III) complexes, Polyhedron, 26, 2007, 1373-1382.

Manuscirpt received:15.10.2019 